\title{
Subgroup Code
}

National Cancer Institute

\section{Source}

National Cancer Institute. Subgroup Code. NCI Thesaurus. Code C93687.

A coded value specifying a subdivision within a larger group. 